\title{
Urban outbreak of acute Chagas disease in Amazon region of Brazil: four-year follow-up after treatment with benznidazole
}

\author{
Ana Yecê das Neves Pinto, ${ }^{1}$ Alberto Gomes Ferreira Jr., ${ }^{2}$ \\ Vera da Costa Valente, ${ }^{1}$ Geraldo Saburo Harada, ${ }^{3}$ \\ and Sebastião Aldo da Silva Valente ${ }^{1}$
}

Suggested citation

Pinto AYN, Ferreira AG, Valente VC, Harada GS, Valente SAS. Urban outbreak of acute Chagas disease in Amazon region of Brazil: four-year follow-up after treatment with benznidazole. Rev Panam Salud Publica. 2009;25(1):77-83.

ABSTRACT The objective of this report is to describe treatment outcomes over a four-year period of patients with acute Chagas disease in the Amazon region of Brazil. An outbreak of Chagas disease in a low-income district of urban Belém, in September 2000, affected 11 people simultaneously, indicating the likelihood of indirect, oral transmission of Trypanosoma cruzi. Prior to treatment, patients underwent physical and clinical tests; blood samples were processed with immunofluorescence assay (IFA) and quantitative buffy coat (QBC). Following treatment with benznidazole, parasitological and serologic tests (artificial xenodiagnosis and blood culture for T. cruzi), electrocardiogram, and echocardiogram were administered at intervals over a fouryear period. Four years after treatment for acute Chagas disease, all patients presented with negative parasitological tests and persistent IgG anti-T. cruzi antibodies with lowered titers; three patients presented electrocardiogram abnormalities consistent with chronic Chagas disease or sequel of acute disease. The satisfactory response to treatment and relevance of serial parasitological examinations of patients with acute Chagas disease are discussed.

Key words Benznidazole; Chagas cardiomyopathy; Chagas disease; disease outbreaks; disease transmission; immunologic tests; Trypanosoma cruzi; Brazil.

Despite efforts to eliminate American trypanosomiasis (Chagas disease) through vector control, the disease continues to

\footnotetext{
1 Chagas Disease Laboratory, Evandro Chagas Institute, Department of Health Surveillance, Ministry of Health, Belém, Brazil. Send correspondence to: Ana Yecê das Neves Pinto, Seção de Parasitologia, Instituto Evandro Chagas, Secretaria de Vigilância em Saúde, BR 316 Km7, Levilândia, Postal code 67030070, Ananindeua, PA, Brazil. Tel: 913214 2150/3214 2043/3214 2151; e-mail: ayece@iec.pa. gov.br.

2 Luiz Décourt Foundation, Belém, Brazil.

3 Instituto do Coração de Belém, Belém, Pará, Brazil.
}

be a public health problem in Latin America. The infection is caused by Trypanosoma cruzi, a parasite transmitted primarily by triatomine vectors found in Mexico and Central and South America. Chagas disease is a complex zoonosis, and the life cycle of the parasite involves a variety of mammal hosts. T. cruzi infection in humans manifests with acute symptomatic or asymptomatic phases and progressive chronic forms with myocardial, esophageal, and intestinal involvement.
An estimated 15 million people in Latin America are infected with T. cruzi, but acute cases are detected in only 1\%$2 \%$ of those infected (1). Some authors point out that there has been an increase in the number of acute cases recorded in some Latin American countries, leading to predictions that the situation regarding Chagas at the beginning of the 21st century will be similar to that in the early years of the 20th century $(2,3)$.

Prior to 1996, acute Chagas disease was rarely reported in the Amazon re- 
gion of Brazil, despite evidence of the complete enzootic cycle of T. cruzi in the region. Outbreaks have since been reported in the region, characterized as short outbreaks involving 2 to 16 acute cases per episode (4). Only five chronic cases are considered autochthonous to the Amazon region. Two of the five patients were symptom-free, two had dilated cardiomyopathy, and one had the digestive form of Chagas disease (5-7).

Acute Chagas disease in the Amazon region of Brazil was first documented by Shaw et al. in 1969 in a low-income area of Belém, Pará state (8). The outbreak involved four family members who fell ill simultaneously in 1968. The absence of triatomine vectors in the family dwelling suggested oral transmission of T. cruzi for the first time in Brazil's Amazon region (8).

Belém is located between Guajará Bay and the Guamá River and has an urban area of $516 \mathrm{~km}^{2}$ with some 1.3 million inhabitants. Preserved forest areas, such as Utinga National Park are on the outskirts of the city. Between 1967 and 1977, single adult insects infected with T. cruzi, particularly Panstrongylus geniculatus and Rhodnius pictipes, were found in households of poor, low-lying suburbs of Belém $(9,10)$. Mammals trapped in forest areas bordering the Pedreira district of Belém, where the 1968 outbreak occurred, had a high prevalence of T. cruzilike trypanosomes $(9,10)$.

Outbreaks in the Amazon region are a target of epidemiological surveillance programs by the Brazilian Ministry of Health because of suspected oral transmission of the parasite. It is problematic to distinguish clinical features of acute Chagas disease in patients infected by vectors and those infected by the oral route. In part this is due to difficulties in obtaining data on acute cases from endemic areas where transmission typically occurs through vectors. Outbreaks involving oral transmission show prolonged febrile illness, a broad spectrum of symptoms, high mortality rates between outbreaks, and no inoculation sites on the body $(11,12)$.

When the acute phase of T. cruzi infection is not detected and treated, it can persist in the indeterminate phase for the life of a patient. Treatment of the acute infection with tripanocidal drugs (benznidazole) has moderate efficacy $(60 \%)$ in eradicating parasites, mainly in patients with a prolonged subacute phase $(11,12)$. Tri- als with patients suffering from chronic or indeterminate phase Chagas disease do not indicate a treatment benefit (13, 14). Andrade et al. presented encouraging findings regarding the efficacy of benznidazole in a randomized controlled trial of children with early chronic $T$. cruzi infection. Their data showed negative seroconversion at the end of a three-year follow-up study in $55.8 \%$ of the children treated with benznidazole, when compared with the placebo group (15). Results from a study in the same cohort of children using the polymerase chain reaction (PCR) method support the notion that negative serology post-treatment corresponds to cure (16).

Better evidence about the clinical profile and treatment outcome of acute phase Chagas disease patients is needed.

We describe an outbreak of acute trypanosomiasis that occurred in September 2000, in the city of Belém. Eleven members of four neighboring families were affected simultaneously, likely as a result of ingesting contaminated food. We describe clinical and laboratory findings during the outbreak and in a fouryear follow-up study. The treatment outcome and relevance of serial parasitological examinations of patients with acute Chagas disease are discussed.

\section{MATERIALS AND METHODS}

Eleven patients from four families were enrolled in the study. The first two patients, a 17-year-old female and her 58-year-old mother, visited the Evandro Chagas Institute in Belém following diagnosis with supposed typhoid fever and treatment with chloramphenicol. Both mother and daughter showed negative results for typhoid fever. Based on clinical evidence of prolonged fever and information about febrile illness in a relative and in neighbors, acute Chagas disease was suspected.

These two patients and nine of their relatives or neighbors with the same history of extensive febrile illness were subsequently diagnosed with trypanosomiasis by parasitological and serologic tests. As far as could be ascertained, all 11 of these individuals were born in the city of Belém and had always lived in the district of Pedreira.

Forty contacts (relatives and neighbors) of the infected individuals were questioned about febrile illness and underwent blood sample collection, re- gardless of whether symptoms were present. Blood samples were examined using immunofluorescence assay (IFA) for immunoglobulin $\mathrm{M}$ (IgM) and immunoglobulin G (IgG), and indirect hemagglutination assay (IHA).

The houses of all patients and their contacts were rigorously searched for triatomine bugs, but none were found.

\section{Case definition}

The case definition for acute Chagas disease is a positive T. cruzi parasitological test (Strout method or thick smear) or a positive serologic test for immunoglobulin M (IgM) anti-T. cruzi antibodies by IFA. When a case is detected, contacts (relatives or neighbors) are immediately screened for infection with blood and parasitological exams, whether or not they are symptomatic (17). Infection cure is defined when three sequential serologic tests, using two different methods, give negative results (17).

A suspicious case is defined as a contact of a diagnosed case who presents febrile illness \pm 15 days from the time the first diagnosed patient became ill.

\section{Clinical and laboratory evaluation}

During the initial evaluation (acute phase), all patients were submitted to clinical and physical examination and blood sampling. Seven series of blood samples were collected: one before onset of treatment (initial), one during treatment (30 days after the onset of treatment), and five following the conclusion of treatment (at 60 days and at 12, 24, 36, and 48 months post-treatment).

The samples collected before treatment were processed using IFA and quantitative buffy coat (QBC) (18).

We added two indirect parasitological methods-artificial xenodiagnosis and blood culture for T. cruzi-to the followup series of examinations. For serum blood culture, a $3 \mathrm{~mL}$ sample of heparinized blood was overlaid on a Hoff agar slant. The overlay was examined by phase contrast microscopy at $400 \times$ magnification every 2 weeks; cultures were discarded as negative after 10 weeks. Xenodiagnosis was performed using 40 fifth-stage nymphs of Triatoma infestans, Triatoma maculata, Triatoma tibiamaculata, Triatoma dimidiata, Panstrongylus megistus, and Dipetalogaster maximus. Rectal contents of individual insects were ex- 
amined for trypanosomes at $400 \times$ magnification one and two months after feeding. Leukocyte counts and hemoglobin concentration studies were made before and after treatment.

Standard 12-lead electrocardiograms (ECG) with the patient at rest and echocardiograms were performed during the first week of treatment and in the third month and fourth year of post-treatment follow-up.

\section{Treatment procedures}

The 11 confirmed cases in the study were treated with benznidazole at doses of 5 to $7 \mathrm{mg} / \mathrm{Kg}$ daily for 60 to 90 days (17). Ten patients received daily treatment for 60 days and, because of treatment failure, one patient received treatment for 90 days.

The ethics committee of the Evandro Chagas Institute approved the study, and all subjects gave informed consent for their participation in this investigation.

\section{RESULTS}

All 11 patients included in this study presented febrile illness and asthenia beginning 7 or 9 September 2000 , lasting between 23 and 43 days. Other reported symptoms and signs were dyspnea, chills, abdominal pain, vomiting, paleness, myalgia, arthralgia, leg swelling, face swelling, cutaneous rash, coughing, and variable degrees of myositis, mainly in the females (Figure 1). Three patients had palpitations, tachycardia, and chest pain. Six patients developed myocarditis and five presented with myopericarditis during the acute phase. Two had serious cardiac manifestations during the acute phase of the disease and required hospitalization. Neither Romaña sign nor other indication of insect inoculation was found on physical examination of the patients.
FIGURE 1. Manifestation of signs and symptoms in 11 patients with acute Chagas disease in Belém, Brazil, 2000

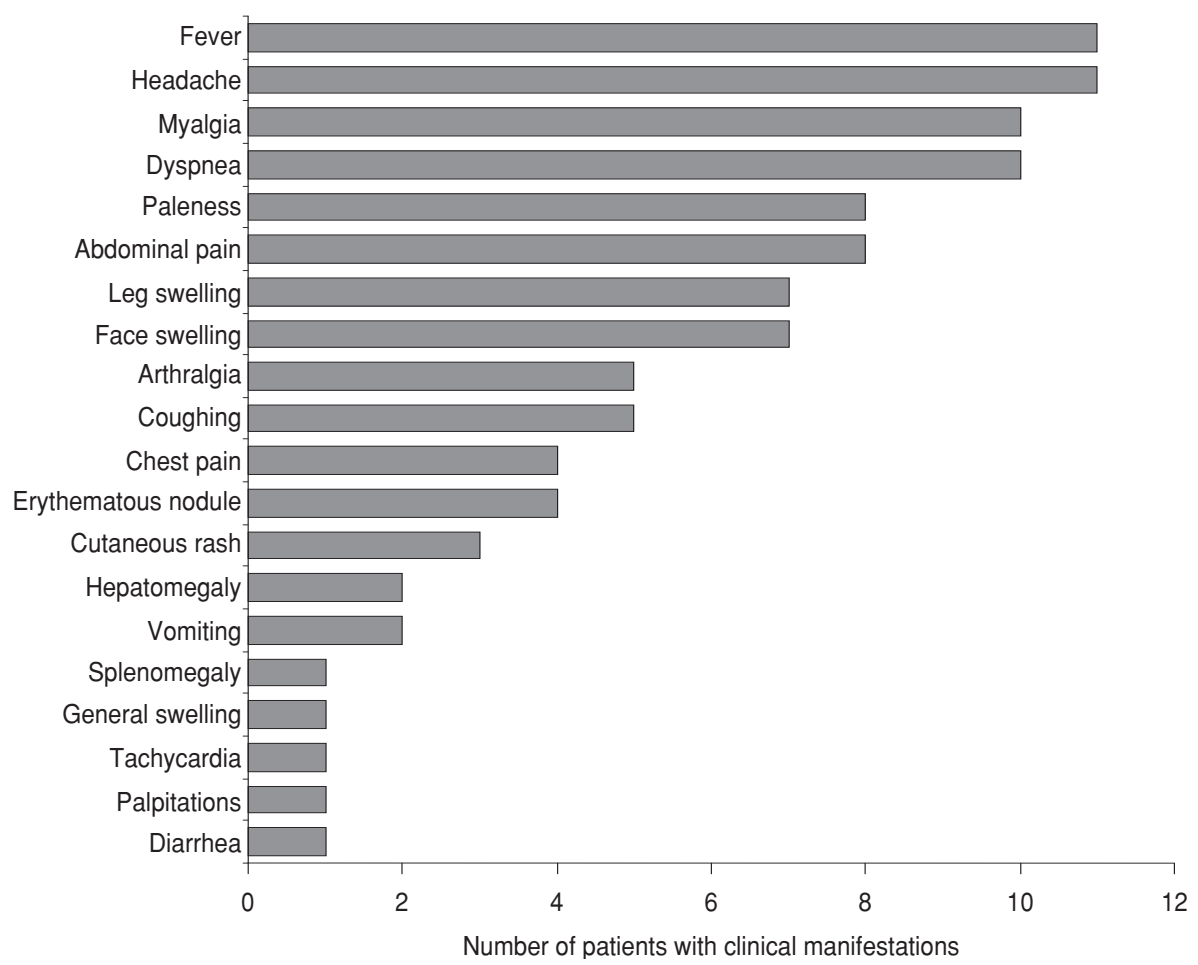

Parasitological tests made immediately after the completion of 30 days of treatment were negative in nine patients. Xenodiagnosis was positive for one 31year-old female at the 30th day of treatment and positive for another 58-yearold female on the 60th day of treatment, indicating treatment failure (Table 1).

Follow-up serologic tests in all patients detected IgM antibodies for a short period and persistent IgG anti-T. cruzi antibodies four years after acute infection. No patients had negative serologic tests until September 2004, four years after treatment (Figure 2).

During the acute phase, five patients presented with anemia (hemoglobin 8.9$10.2 \mathrm{~g} / \mathrm{dL}$ ). Leukocyte counts increased in two patients who presented with acute pulmonary infections simultaneously with acute Chagas disease. Four patients had lymphocytosis (1 702-8979 lymphocytes $/ \mathrm{mm}^{3}$ ) during the acute illness, with improvement after two months. Three patients presented with leukopenia (3 200-4 700 leukocytes $/ \mathrm{mm}^{3}$ ).

ECG and echocardiogram results during the acute illness and at four years post-treatment are shown in Table 2. Five patients had no ECG changes through the follow-up period. One patient had low QRS voltage due to pericardial effusion. Four patients presented non-specific ventricular repolarization with or without associated conduction disturbances. Of these four, the ECGs of two patients

TABLE 1. Parasitological results in follow-up of treatment of 11 patients presenting acute Chagas disease, Belém, Brazil; 2000-2004

\begin{tabular}{|c|c|c|c|c|c|c|c|c|c|c|c|c|}
\hline \multirow[b]{4}{*}{ Days following treatment } & \multicolumn{12}{|c|}{ Test results for patients } \\
\hline & \multicolumn{4}{|c|}{ Quantitative buffy coat } & \multicolumn{4}{|c|}{ Blood culture } & \multicolumn{4}{|c|}{ Xenodiagnosis } \\
\hline & \multicolumn{2}{|c|}{ Positive } & \multicolumn{2}{|c|}{ Negative } & \multicolumn{2}{|c|}{ Positive } & \multicolumn{2}{|c|}{ Negative } & \multicolumn{2}{|c|}{ Positive } & \multicolumn{2}{|c|}{ Negative } \\
\hline & No. & $\%$ & No. & $\%$ & No. & $\%$ & No. & $\%$ & No. & $\%$ & No. & $\%$ \\
\hline First day & 8 & 72.3 & 3 & 27.3 & 8 & 72.3 & 3 & 27.3 & 11 & 100 & 0 & \\
\hline 30 days & 0 & & 11 & 100 & 0 & & 11 & 100 & 2 & 18 & 9 & 82 \\
\hline 60 days & 0 & & 11 & 100 & 0 & & 11 & 100 & 1 & 9 & 10 & 91 \\
\hline 1 year & 0 & & 11 & 100 & 0 & & 11 & 100 & 0 & & 11 & 100 \\
\hline 3 years & 0 & & 11 & 100 & 0 & & 11 & 100 & 0 & & 11 & 100 \\
\hline
\end{tabular}


FIGURE 2. Change in titers of IgG anti-Trypanosoma cruzi antibodies by immunofluorescence assay (IFA) during the acute phase and four years following treatment in 11 Chagas disease patients in Belém, Brazil, 2000-2004

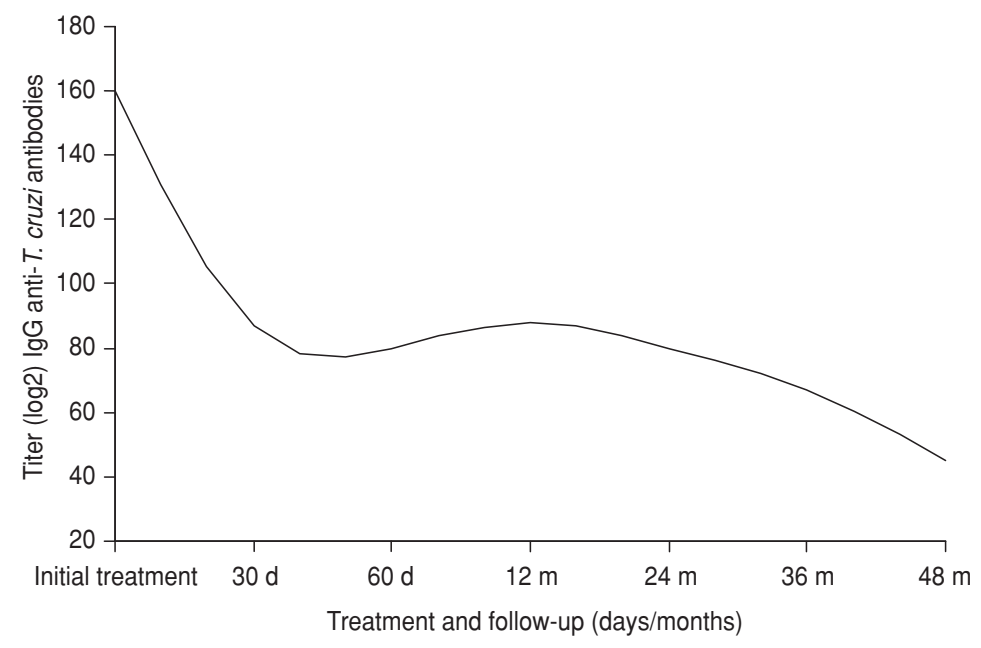

normalized, one 17-year-old female remained with atrioventricular (AV) dissociation and intermittent left bundlebranch block, and one 15-year-old female developed right bundle-branch block plus fascicular left bundle-branch block.

Three patients presented pericardial effusion that resolved shortly after onset of treatment. One 28-year-old male had a moderate amount of fluid in the pericardium and significant myositis in both lower limbs. Echocardiography of a 70year-old female with prior history of arterial hypertension showed abnormalities before and after treatment that were consistent with diastolic dysfunction and signs of hypertrophy due to her previous condition. None of the patients presented decreased ejection fraction either during acute illness or later (see Table 2).

All 40 contacts (relatives and neighbors) examined were asymptomatic and had negative serologic tests.

\section{DISCUSSION}

The signs and symptoms described in the Chagas outbreak reviewed in this study reveal a prolonged, febrile syndrome illness and positive parasitological and serologic tests. All patients showed persistent titers of IgG anti-T. cruzi antibodies four years after acute infection, but with an important decrease over time. While these lowered titers suggest a high possibility of cure, the outcomes for the patients remain uncertain.

Despite the low sensitivity of parasitological tests in cure assessment, we performed these tests during, before, and after treatment. Xenodiagnosis showed that two patients had persistent parasitemia at days 30 and 60 of treatment. Both continued medication for an additional 30 days. There was no difference in response to treatment between the pa-

TABLE 2. Results of electrocardiograms and echocardiograms during acute phase and four years post-treatment in 11 Chagas disease patients in Belém, Brazil, 2000-2004

\begin{tabular}{|c|c|c|c|c|c|c|}
\hline Case No. & $\begin{array}{l}\text { Age } \\
\text { (years) }\end{array}$ & Gender & $\begin{array}{l}\text { Acute phase } \\
\text { electrocardiogram } \\
\text { results }\end{array}$ & $\begin{array}{l}\text { Post-treatment } \\
\text { electrocardiogram } \\
\text { results } \\
\text { (fourth year) }\end{array}$ & $\begin{array}{l}\text { Acute phase } \\
\text { echocardiogram } \\
\text { results }\end{array}$ & $\begin{array}{l}\text { Post-treatment } \\
\text { echocardiogram } \\
\text { results } \\
\text { (fourth year) }\end{array}$ \\
\hline 2 & 28 & $\mathrm{~F}$ & Normal & Normal & $\ldots$ & Normal \\
\hline 3 & 31 & $\mathrm{~F}$ & Left axis deviation & $\begin{array}{l}\text { Left axis deviation, left anterior } \\
\text { fascicular block }\end{array}$ & Normal; $E F=69 \%$ & Normal \\
\hline 5 & 28 & M & $\begin{array}{l}\text { First-degree atrioventricular block; } \\
\text { non-specific repolarization changes }\end{array}$ & Normal & $\begin{array}{l}\text { Moderate pericardial effusion; } \\
\mathrm{EF}=63 \%\end{array}$ & Normal \\
\hline 6 & 17 & $\mathrm{~F}$ & $\begin{array}{l}\text { Non-specific repolarization changes; } \\
\text { atrioventricular dissociation; left axis } \\
\text { deviation }\end{array}$ & $\begin{array}{l}\text { Atrioventricular dissociation; } \\
\text { intermittent left bundle-branch } \\
\text { block }\end{array}$ & $\begin{array}{l}\text { Mild pericardial effusion; left } \\
\text { ventricular dilatation with diffuse } \\
\text { hypokinesis; moderate mitral } \\
\text { regurgitation; } E F=56 \%\end{array}$ & Normal \\
\hline 8 & 19 & M & Normal & Normal & $\ldots$ & Normal \\
\hline 9 & 15 & $\mathrm{~F}$ & Non-specific repolarization changes & $\begin{array}{l}\text { Right bundle-branch block, } \\
\text { left posterior fascicular block }\end{array}$ & Normal; $E F=74 \%$ & Normal \\
\hline 10 & 24 & $\mathrm{~F}$ & Normal & Normal & Mild pericardial effusion; $E F=70 \%$ & Normal \\
\hline 11 & 58 & $\mathrm{~F}$ & Normal & Normal & $\begin{array}{l}\text { Left ventricular hypertrophy; } \\
E F=68 \%\end{array}$ & Normal \\
\hline
\end{tabular}


tient receiving benznidazole for 90 days and the patient receiving it for 60 days. Four years after treatment, both of these patients showed low IgG antibody titers $(1 / 40)$ and negative parasitological tests. We cannot be certain that these two patients followed the prescribed dosing schedules during the first 60 days of treatment.

Our findings show the potential benefits of benznidazole for clinical improvement of acute cases. However, the failure of benznidazole to clear parasitemia (as shown by xenodiagnosis and blood culture) in two patients by days 30 and 60 of treatment, suggests the need for new treatment schedules with longer duration. In addition, we do not know the significance of low IgG titers during the follow-up series of tests, but we hypothesize that it represents immunological memory rather than parasite persistence. More extensive follow-up or other effective tests are necessary to evaluate cure.

The rates of ECG abnormalities and cardiac disease during the acute phase reported in this study are similar to those reported in endemic areas $(19,20)$. Abnormalities compatible with acute Chagas disease showed rapid clinical improvement following treatment. One patient showed minimal echocardiography alterations consistent with acute myocarditis that disappeared after treatment. Similar results were encountered in a study of 37 patients with acute Chagas disease in an endemic area. These patients had temporary alterations of the cardiac autonomic conduction system $(19,3)$.

Early lesions of the cardiac conduction system have been documented in patients from a Chagas endemic area in Brazil. Pazin-Filho et al. showed that mild segmental left ventricular wall motion abnormalities in echocardiograms of patients with chronic disease could indicate future worsening of systolic function (21). In our post-treatment followup, chronic Chagas disease is indicated in three patients on the basis of these ECG findings: left anterior fascicular block, atrioventricular dissociation and intermittent left bundle-branch block, and right bundle-branch block and left posterior fascicular block, despite there being no clinical manifestation of these conditions. We do not know if the persistent ECG abnormalities indicate chronic phase of Chagas disease despite all patients having undergone treatment dur- ing the acute phase, or if these abnormalities represent sequelae of acute myocardial attack in patients who are free of the parasite. Patients with abnormal ECGs four years after treatment suggest that these early lesions are common and can go undetected, as we observed in the follow-up of patients. Long-term observation is needed to determine whether overt clinical disease will appear or if these abnormalities persist as mild sequelae of the acute phases.

Pericardial effusion resulting in death has been documented in patients with acute Chagas disease in outbreaks in the municipalities of Abaetetuba and Cametá, both in Pará state in Brazil's Amazon region. In the Cametá outbreak, two deaths due to acute myopericarditis occurred $(22,23)$. In our study, three patients presented mild pericardial effusion without relationship either to ECG conduction disturbances or low ejection fraction in echocardiogram. This sug-

FIGURE 3. Location of triatomine bugs collected in districts of Belém, Brazil, 1967-1977

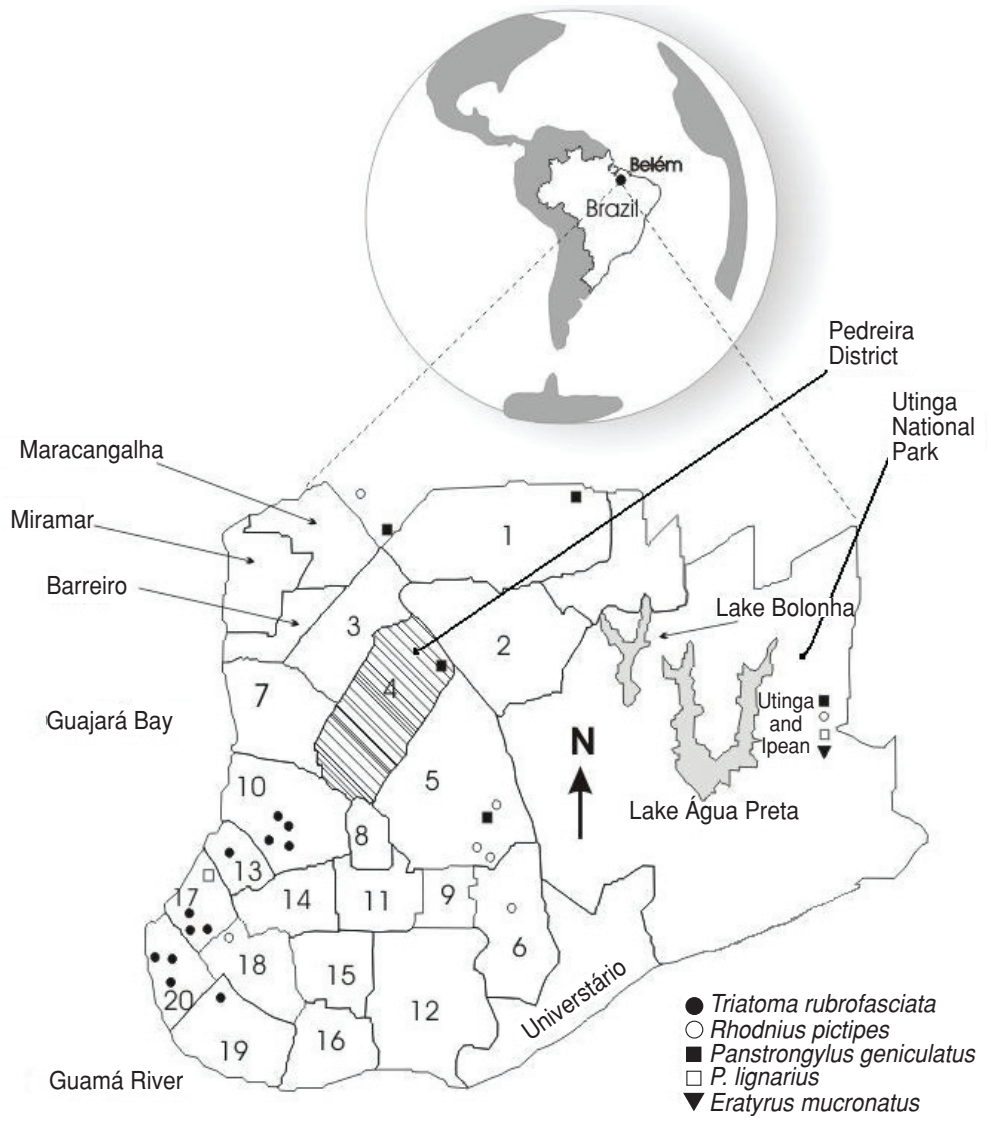

Districts: 1. Marambaia; 2. Souza; 3. Sacramenta; 4. Pedreira; 5. Marco; 6. Terra Firme; 7. Telégrafo; 8. Matinha; 9. Canudos; 10. Umarizal; 11. São Braz; 12. Guamá; 13. Reduto; 14. Nazaré; 15. Cremação; 16. Condor; 17. Comércio; 18. Batista Campos; 19. Jurunas; 20. Cidade Velha

Source: Adapted by N. Veiga from Lainson et al, 1979. Used with permission. gests that the presence of pericardial effusion may be part of a generalized process of inflammation with important repercussions for the pericardium rather than the myocardium. While myocarditis is more consistent with acute Chagas disease, pericarditis is described as a consequence of direct parasite lesions in acute cases from endemic areas, and should not be disregarded in cases in the Amazon region.

Epidemiologic investigation found no signs of triatomine vectors in the households of the patients and their contacts in our study. Onset of symptoms occurred within two to four days for all 11 of the affected individuals, suggesting oral transmission due to indirect contact with triatomine bugs. The presence of triatomines infected with T. cruzi in Pedreira district has been documented, as well as a $17.4 \%$ T. cruzi infection rate in wild mammals on the outskirts and in forests bordering Belém, mainly in the

(a)

.


National Park of Utinga located near the Pedreira district (see the map in Figure 3) (9). This could be evidence of indirect and accidental human contact with this vector in this well-defined area of Belém, where acute cases of Chagas disease have occurred. The four families included in this study did not participate in gatherings where they would have shared food. It is improbable that infected triatomine bugs could infect three or more people concurrently, and that symptoms would present nearly simultaneously. We suggest that transmission of T. cruzi in this group of patients occurred orally, possibly involving an unprocessed beverage frequently consumed by this population. When prepared in unclean conditions this drink could be contaminated, as documented in a similar outbreak in Amapá state (24).

Brazilian researchers suggest that the increased risk for endemic Chagas disease in the Amazon is related to deforestation, population settlements, shifting cultivation, human colonization of the vector's natural ecotopes, and human migration to the Amazon region from endemic areas. Chagas disease in humans has been described in limited geographic areas in the Amazon region, especially northeastern Pará state and southeastern Amapá state, related to sylvatic and port areas or areas that have experienced rapid urbanization and increased population density in the last 10 years (4, 25-29). In northeastern Pará state, an extensive highway project may have caused an important ecological imbalance that has contributed to disturbing triatomine ecotopes.

There are many unanswered questions regarding contact between sylvatic vectors and human hosts of Trypanosomas in the Brazilian Amazon. We know that acute infection is benign in the majority of cases of Chagas, but poor clinical outcomes are possible when delayed diagnosis and delayed host response occurs. Serious pericarditis may be lethal to patients in the acute phase of the disease.
Clinical outcomes of patients during this brief follow-up of an urban Trypanosomiasis outbreak suggest that chronic Chagas disease in the Amazon region may be underestimated, although all patients in this study were symptomatic during the acute phase, unlike those affected in endemic areas. The authors underscore the need for a strong surveillance system for Chagas disease in the Amazon region of Brazil.

Acknowledgments. We are grateful to José Elson Abud, Francisco Gomes, Aguinaldo Ferreira, and Gilberto César Rodrigues for technical support in carrying out this study. We acknowledge Ralph Lainson who gave us permission to adapt the published version of the map of Belém, and Nelson Veiga and his colleagues for adapting the map. We are indebted to Sheila Maria Almeida Ferreira Gomes for comments on the text. Financial support was provided by the Evandro Chagas Institute, UNESCO, and the Luiz Décourt Foundation (Belém).

\section{REFERENCES}

1. Word Health Organization. Control of Chagas disease. Geneva: WHO; 2002. (Technical Report Series 905). 109 p.

2. Medrano-Mercado N, Luz M, Torrico F, Tapia G, Van Leuven F, Araújo-Jorge TC. Acutephase proteins and serological profiles of chagasic children from an endemic area in Bolivia. Am J Trop Med and Hyg. 1996;54(2): 154-61.

3. Parada H, Carrasco HA, Añez N, Fuenmayor C, Inglessis I. Cardiac involvement is a constant finding in acute Chagas' disease: a clinical, parasitological and histopathological study. Int J Cardiol. 1997; 60(1):49-54.

4. Valente SA, Valente VC, Fraiha H. Considerations on the epidemiology and transmission of Chagas disease in the Brazilian Amazon. Mem Inst Oswaldo Cruz. 1999;94(Suppl 1): 395-8.

5. Valente VC, Crescente JA, Valente SAS, Araújo JEA. Doença de Chagas em fase indeterminada detectada em 2 doadores de sangue no Estado do Pará. Summary presented at the XXVIII Congresso da Sociedade Brasileira de Medicina Tropical; Belém, March 1992. Pp. 37-8.

6. Valente VC, Pinto AYN, Valente SAS, Ostermayer AL. Considerações sobre um possível caso de megacólon por doença de Chagas autóctone no Estado do Pará. Rev Soc Bras Med Trop. 1995;28(Suppl III):99-100.

7. Albajar PV, Laredo SV, Terrazas MB, Coura JR. Miocardiopatia dilatada em pacientes com infecção chagásica crônica. Relato de dois casos fatais autóctones no Rio Negro, estado do Amazonas. Rev Soc Bras Med Trop. 2003; 36(3):401-7.

8. Shaw JJ, Lainson R, Fraiha H. Considerações sobre a epidemiologia dos primeiros casos autóctones de doença de Chagas registrados em Belém, Pará, Brasil. Rev Saúde Pública. 1969;3(2):153-7.

9. Lainson R, Shaw JJ, Fraiha H, Miles MA, Draper CC. Chagas disease in the Amazon Basin 1. Trypanosoma cruzi infections in sylvatic mammals, triatomine bugs and man in the State of Pará, north Brazil. Trans R Soc Trop Med Hyg. 1979;73(2):193-204.

10. Miles MA, Souza AA, Póvoa M. Chagas disease in the Amazon basin III. Ecotopes of ten triatomine bug species (Hemiptera: Reduviidae) from the vicinity of Belém, Pará State, Brazil. J Med Entomol. 1981;18(4):266-78.

11. Brazil, Ministry of Health, Department of Health Surveillance [Secretaria de Vigilância em Saúde]. Doença de Chagas aguda relacionada à ingestão de caldo de cana em Santa Catarina. Brasília, 2005 [Internet site]. Available from: http://www.anvisa.gov.br/ DIVULGA/NOTICIAS/2005/240305_nota. pdf. Accessed 17 July 2008.

12. Valente SA, Valente VC, Pinto AYN. Epidemiologia e transmissão oral da doença de Chagas na Amazônia brasileira. In: Organización Panamericana de la Salud/Organización Mundial de la Salud. Unidad Regional de Prevención y Control de Enfermedades Transmisibles, Grupo Técnico Especializado en Inocuidad de Alimentos. Informe de la consulta técnica en Epidemiología, Prevención y Ma- nejo de la Transmisión de la Enfermedad de Chagas como Enfermedad Transmitida por Alimentos (ETA), Rio de Janeiro, May 2006. Pp. 21-6.

13. Ferreira HO. Tratamento da forma indeterminada da doença de Chagas com nifurtimox e benzonidazol. Rev Soc Bras Med Trop. 1990; 23(4):209-11.

14. Villar JC, Villar LA, Marin-Neto JA, Ebrahim S, Yusuf S. Trypanocidal drugs for chronic asymptomatic Trypanosoma cruzi infection. Cochrane Database Syst Rev. 2002;(1): CD003463.

15. Andrade AL, Martelli CM, Oliveira RM, Silva SA, Aires AI, Soussumi LMT, et al. Short report: benznidazole efficacy among Trypanosoma cruzi-infected adolescents after a sixyear follow-up. Am J Trop Med Hyg. 2004; 71(5):594-7.

16. Galvão LM, Chiari E, Macedo AM, Luquetti AO, Silva SA, Andrade AL. PCR assay for monitoring Trypanosoma cruzi parasitemia in childhood after specific chemoterapy. J Clin Microbiol. 2003;41(11):5066-70.

17. Brazil, Ministry of Health, Department of Health Surveillance [Secretaria de Vigilância em Saúde]. Consenso brasileiro em doença de Chagas. Rev Soc Bras Med Trop. 2005;38 (Suppl. III):30.

18. Levine RA, Wardlaw SC, Patton CL. Detection of haemotoparasites using quantitative buffy coat analysis tubes. Parasitol Today. 1989;5(4):132-4.

19. Rassi A, Ferreira HO. Tentativa de tratamento específico da fase aguda de doença de chagas 
com nitrofuranos em esquemas de duração prolongada. Rev Soc Bras Med Trop. 1971; 5(5):235-62.

20. Cançado JR. Tratamento etiológico da Doença de Chagas pelo benzonidazol. In: Brener Z, Andrade Z, Barra-Neto M, eds. Trypanosoma cruzi e doença de Chagas. 2nd edition. Rio de Janeiro: Guanabara Koogan; 2000. Pp. 389-405.

21. Pazin-Filho A, Romano MMD, Almeida-Filho JA, Marin-Neto OC, Furuta MS, Viviani LF, et al. Minor segmental wall motion abnormalities detected in patients with Chagas' disease have adverse prognostic implications. Braz J Med Biol Res. 2006;39(4);483-7.

22. Pinto AYN, Harada GS, Valente VC, Abud JEA, Gomes FS, Souza GCR, et al. Acometimento cardíaco em pacientes com doença de Chagas aguda em microepidemia familiar, em Abaetetuba, na Amazônia brasileira. Rev Soc Bras Med Trop. 2001;34(5):413-9.
23. Pinto AY, Valente SA, Valente VC. Emerging acute Chagas disease in Amazonian Brazil: case reports with serious cardiac involvement. Braz J Infect Dis. 2004:8(6):454-60.

24. Valente SAS, Valente VC, César MJB, Santos MP. Registro de 15 casos autóctones de doença de Chagas no Estado do Amapá com evidências de transmissão oral. Summary presented to the XXXIII Congresso da Sociedade Brasileira de Medicina Tropical, 4-7 March 1997; Belo Horizonte.

25. Valente VC, Valente SA, Noireau F, Carrasco HJ, Miles MA. Chagas' disease in the Amazon Basin: association of Panstrongylus geniculatus (Hemiptera: Reduviidae) with domestic pigs. J Med Entomol. 1998;35(2):99-103.

26. Coura JR, Junqueira AC, Fernandes O, Valente SA, Miles MA. Emerging Chagas disease in Amazonian Brazil. Trends Parasitol. 2002; 18(4):171-6.
27. Ferraroni JJ, Melo JA, Camargo ME. Molestia de Chagas na Amazônia: ocorrência de seis casos suspeitos, autóctones, sorologicamente positivos. Acta Amazônica. 1977;7(3):438-40.

28. Rodrigues CI, Souza AA, Terceros R, Valente SA. Doença de Chagas na Amazônia: registro de oito casos autóctones em Macapá. Rev Soc Bras Med Trop. 1988;21(4):193-7.

29. Teixeira AR, Monteiro PS, Rebelo JM, Argañaraz ER, Vieira D, Lauria Pires L, et al Emerging Chagas disease: trophic network and cycle of transmission of Trypanosoma cruzi from palm trees in the Amazon. Emerg Infect Dis. 2001;7(1):100-12.

Manuscript received on 1 January 2008. Revised version accepted for publication on 2 April 2008.

RESUMEN El objetivo de este informe es describir los resultados del tratamiento para la enfermedad aguda de Chagas durante un seguimiento de cuatro años en pacientes de la región amazónica de Brasil. Un brote de la enfermedad de Chagas en un distrito de bajos ingresos de la parte urbana de Belém afectó simultáneamente a 11 personas en septiembre de 2000; al parecer, la transmisión de Trypanosoma cruzi fue indirecta por vía oral. Antes del tratamiento, los pacientes se sometieron a un examen físico y pruebas clínicas; las muestras de sangre se estudiaron mediante inmunofluorescencia indirecta y análisis cuantitativo de la capa leucocitaria (buffy coat). Después del tratamiento con benznidazol se realizaron pruebas parasitológicas y serológicas (xenodiagnóstico artificial y hemocultivo de T. cruzi), electrocardiogramas y ecocardiogramas periódicos durante cuatro años. Cuatro años después del tratamiento por enfermedad aguda de Chagas, todos los pacientes eran negativos en los análisis parasitológicos y disminuyeron los títulos de anticuerpos IgM anti-T. cruzi persistentes; tres pacientes presentaron alteraciones electrocardiográficas indicadoras de enfermedad crónica de Chagas o de secuelas de la enfermedad aguda. Se discute la respuesta satisfactoria al tratamiento y la importancia de los análisis parasitológicos seriados de los pacientes con enfermedad aguda de Chagas.

Palabras clave Cardiomiopatía chagásica, enfermedad de Chagas, brotes de enfermedades, transmisión de enfermedad, pruebas inmunológicas, Trypanosoma cruzi, Brasil. 